Recherches en didactique des langues et des cultures

Les cahiers de l'Acedle

18-1 | 2021

En quoi les langues ont-elles un rôle à jouer dans les sociétés mondialisées au sein d'une Europe fragilisée ?

\title{
Conceptions de la didactique des langues
}

Acedle, Asdifle et TRANSIT-Lingua

\section{(2) OpenEdition}

\section{Journals}

Édition électronique

URL : https://journals.openedition.org/rdlc/8875

DOI : $10.4000 /$ rdlc. 8875

ISSN : 1958-5772

Éditeur

ACEDLE

Référence électronique

Acedle, Asdifle et TRANSIT-Lingua, "Conceptions de la didactique des langues », Recherches en

didactique des langues et des cultures [En ligne], 18-1 | 2021, mis en ligne le 10 juin 2021, consulté le 03 août 2021. URL : http://journals.openedition.org/rdlc/8875 ; DOI : https://doi.org/10.4000/rdlc.8875

Ce document a été généré automatiquement le 3 août 2021

\section{cc) (†) $\odot$}

Recherches en didactique des langues et des cultures is licensed under a Creative Commons AttributionNonCommercial-NoDerivatives 4.0 International License 


\title{
Conceptions de la didactique des langues
}

\author{
Acedle, Asdifle et TRANSIT-Lingua
}

1 [A venir dans le courant de l'automne 2021]

2 Cette capsule synthétise les moments du débat participatif concernant les conceptions de la didactique des langues : quelle.s histoire.s de la didactique des langues? Quels rapports aux dimensions instrumentales et/ou philologiques? Quelle.s place.s pour les dispositifs ? La médiation? La pluralité linguistique et culturelle?

Ce média ne peut être affiché ici. Veuillez vous reporter à l'édition en ligne http:// journals.openedition.org/rdlc/8875

\section{Chapitrage de la capsule}

\section{AUTEURS}

ACEDLE

https://acedle.org/

ASDIFLE

https://asdifle.com/ 
TRANSIT-LINGUA

https://transitlingua.org/ 